\title{
Self-care with the skin of Community Health Agents
}

\author{
Georgia Stefani Cardoso de Camargo, Magna Cristina da Silva Fonseca, Sávia Denise Silva \\ Carlotto Herrera, Najla de Oliveira Mahmud, Florence Germaine Tible Lainscek, Núbia Martins \\ Correia, Wellington Bispo Nunes, Warly Neves de Araújo
}

\begin{abstract}
This document gives formatting guidelines for authors preparing papers for publication in the International Journal of Engineering and Applied Sciences. The authors must follow the instructions given in the document for the papers to be published. The margins must be set as follows: Top $=1.7 \mathrm{~cm}$, Bottom $=1.7 \mathrm{~cm}$, left $=1.7 \mathrm{~cm}$, Right $=1.7 \mathrm{~cm}$. Paper Title must be in Font Size 22, with Single Line Spacing. Authors Name must be in Font Size 11. Abstract should contain at least 250 words. Abstract explanation should be Times New Roman font, 09 Size, Bold, Single line spacing, text alignment should be justified. References and Author's Profile must be in Font Size 8, Hanging 0.25 with single line spacing.
\end{abstract}

Index Terms - Community health agent, Aging of the skin, Sun exposure /solar radiation, Skin injury.

\section{INTRODUCTION}

The Community Health Agent (CHA) is an indispensable component in the Family Health Strategy Team (FHS), which is the main program that provides access to primary health care services (PHC) in the Unified Health System (SUS). The CHA is a fundamental member of the community, representing a link between the user and the health service. According to the National Primary Care Policy (MPCP, 2012) performs functions such as: registering and accompanying families restricted to their micro area, guiding them on the use of health services, promoting actions that seek integration between the FHS and the community; develop activities of health promotion, disease prevention, health surveillance, through home visits and individual and collective educational actions [1].

According to Martines [2], CHA tends to have a higher

Georgia Stefani Cardoso de Camargo, Graduate student in Physiotherapy, University of Gurupi UnirG, Avenue. Rio de Janeiro. N 。 1585-Sector. Central., Gurupi, 77403-090, Tocantins, Brazil

Magna Cristina da Silva Fonseca, Graduate student in Physiotherapy, University of Gurupi UnirG, Avenue. Rio de Janeiro. N • 1585-Sector. Central., Gurupi, 77403-090, Tocantins, Brazil.

Sávia Denise Silva Carlotto Herrera, Physiotherapist. Teacher. Assistant I of Gurupi University - UnirG, Avenue. Rio de Janeiro. N $\circ 1585$-Sector. Central., Gurupi, 77403-090, Brazil.

Najla de Oliveira Mahmud, in Physiotherapy from the Higher Education Unit of Southern Maranhão - UNISULMA-MA, Brazil

Florence Germaine Tible Lainscek, Master's Degree in Health Sciences, Federal University of Tocantins. Professor of the Physiotherapy Course of Gurupi University - UnirG, Gurupi-TO, Brazil

Núbia Martins Correia, Graduate student in Physiotherapy, University of Gurupi UnirG, Avenue. Rio de Janeiro. N • 1585-Sector. Central., Gurupi, 77403-090, Tocantins, Brazil

Wellington Bispo Nunes, Graduate student in Physiotherapy, University of Gurupi UnirG, Avenue. Rio de Janeiro. N • 1585-Sector. Central., Gurupi, 77403-090, Tocantins, Brazil

Warly Neves de Araujo, Graduated in Physiotherapy, University of Gurupi UnirG,, Gurupi, Tocantins, Brazil prevalence of signs of premature aging when compared to other members of the Basic Health Unit (BHU) such as the physician, nurse and nursing assistant who are inside the Unit and with a lower frequency of sun exposure. The CHA spends most of their hours on the streets exposed to solar radiation.

Although exposure to sunlight is essential in the lives of humans, as it benefits vitamin D production and melanin production stimulation, these effects depend on factors such as intensity, frequency, and exposure time. Excess and unprotected solar radiation promote changes in the body such as premature aging and even skin cancer [3].

According to Montagner and Costa[4] ultraviolet rays (UV) are divided into two types of solar radiation that exceed the ozone layer, RUV-B which is the biggest cause of skin cancer, and UV-A that alters cells and stimulates the development of malignant melanoma, in addition to favoring premature aging, both UV radiations can generate skin lesions due to free radicals in deoxyribonucleic acid (DNA).

With the expansion of industrialization and excessive pollution due to man's action, the ozone layer is increasingly thin and losing its role of protection against sunlight. In foods such as carrot, tomato, and papaya lies beta carotene sustância that increases the reaction of ultraviolet sensitivity photos [5] [6].

There is an increasing number of individuals with premature aging, as a large part of the population to develop their work activities is exposed to solar radiation in a long period during the day [7].

According to Carvalho [8], the skin aged due to extrinsic factors such as ultraviolet radiation differs from physiological aging, because it looks paler, rough the appearance of sagging is more remarkable, presents thicker wrinkles at the time of facial expression, it is remarkable the presence of hypo and hyperpigmented lesions (senile spots) in people with a history of excessive sun exposure.

\section{MATERIALS AND METHODS}

This is bibliographical research carried out from the survey of articles in the database, Virtual Health Library (Medline, Lilacs), SciELO, about self-care with the skin. The following terms were used for the search: Community health agent; aging of the skin; sun exposure /solar radiation; skin injury. Twenty-seven articles were identified, of which only 13 articles contained the terms searched in the title of the study and were published from 2015 to 2020 . The articles were read in full and used to compose the results and discussion of the present study.

During the bibliographic survey, the content of the articles eliminated was analyzed the articles that did not include the theme of self-care with the skin. The inclusion criteria defined for the selection of articles were: articles found in the language 
Portuguese, published in the period from 2015 to 2020 years, available in full and that addressed the theme investigated.

The collected data were discussed by students responsible for the production of the article and with the help of Microsoft Word 2010 and Microsoft Excel 2010, arranged in the form of development for later confrontation with the literature.
The analyses of the results obtained by this study were based on the following bibliometric indicators: year of publication of the study, authors, type of study. In the present study, 27 articles were found, 13 of which were selected for the study. The following information was condensed: authors, year of publication, type of study, methodology, and outcomes, according to table 1 .

\section{RESULTS}

\begin{tabular}{|c|c|c|c|c|c|}
\hline NUMBER & $\begin{array}{c}\text { AUTHOR/ } \\
\text { YEAR }\end{array}$ & $\begin{array}{l}\text { TYPE OF } \\
\text { STUDY }\end{array}$ & OBJECTIVE & METHODOLOGY & OUTCOME \\
\hline 1 & $\begin{array}{l}\text { Cortez et al., } \\
2016 \text { [9] }\end{array}$ & $\begin{array}{l}\text { Exploratory - } \\
\text { descriptive with a } \\
\text { qualitative } \\
\text { approach. }\end{array}$ & $\begin{array}{l}\text { To determine the level } \\
\text { of instruction of } \\
\text { professionals in the field } \\
\text { of aesthetics regarding } \\
\text { the use of sunscreen, } \\
\text { and also identify the } \\
\text { guidelines they pass on } \\
\text { to their patients. }\end{array}$ & $\begin{array}{l}\text { The municipality of } \\
\text { Maringá-PR, } \\
\text { southern Brazil, was } \\
\text { elected as the study } \\
\text { site, due to the large } \\
\text { number of clinics and } \\
\text { beauty salons it has, } \\
\text { 196, from March to } \\
\text { September } 2013 \text {. } \\
\text { The sample was } \\
\text { random, composed of } \\
30 \text { female } \\
\text { professionals, the } \\
\text { mean age of } 28 \text { (19 to } \\
41 \text { ) years, } \\
\text { technologists and } \\
\text { technicians in } \\
\text { aesthetics, and } \\
\text { physiotherapists, and } \\
\text { physical educator. }\end{array}$ & $\begin{array}{l}\text { The results showed } \\
\text { that among the } \\
\text { professionals } \\
\text { interviewed there is } \\
\text { a conscious use of } \\
\text { sunscreens, who } \\
\text { have good } \\
\text { knowledge about } \\
\text { these products and } \\
\text { the importance and } \\
\text { need of this product } \\
\text { for the prevention of } \\
\text { cutaneous } \\
\text { neoplasms. } \\
\text { It also showed the } \\
\text { commitment } \\
\text { professionals to } \\
\text { guide their users to } \\
\text { the correct use of } \\
\text { topical } \\
\text { photoprotector. }\end{array}$ \\
\hline
\end{tabular}




\begin{tabular}{|c|c|c|c|c|c|}
\hline 2 & $\begin{array}{l}\text { Castro et al., } \\
2018[10]\end{array}$ & $\begin{array}{l}\text { The quantitative } \\
\text { approach, } \\
\text { cross-sectional } \\
\text { outline. }\end{array}$ & $\begin{array}{l}\text { To be worth the } \\
\text { prevalence and } \\
\text { prevention habits of skin } \\
\text { cancer in rural elderly. }\end{array}$ & $\begin{array}{l}\text { An estimated sample } \\
\text { calculation was } \\
\text { performed for frailty } \\
\text { syndrome using the } \\
\text { following parameters: } \\
\text { population of the city } \\
\text { of Pelotas-RS - } \\
328.2759 \text {, confidence } \\
\text { level of 95\%, the } \\
\text { prevalence of frailty } \\
\text { syndrome estimated } \\
\text { at } 19.9 \% \text { and } \\
\text { acceptable error of } \\
3 \% \text { With these data, } \\
\text { the initial calculation } \\
\text { base was } 680 \text {, totaling } \\
10 \% \text { of losses, } 10 \% \\
\text { of refusals, and } 10 \% \\
\text { for control of } \\
\text { confounding factors, } \\
834 \text { were totaled as } \\
\text { sample calculation, } \\
\text { and } 820 \text { elderly were } \\
\text { interviewed. }\end{array}$ & $\begin{array}{l}\text { The results of this } \\
\text { study show that } \\
\text { rural elderly is part } \\
\text { of the risk group for } \\
\text { skin cancer due to } \\
\text { prolonged hours of } \\
\text { sun exposure and } \\
\text { few prevention } \\
\text { measures are } \\
\text { adopted. } \\
\text { prevalence The } \\
\text { self-reported skin } \\
\text { cancer by the elderly } \\
\text { studied was } 4.8 \% \text {. } \\
\text { Considering the } \\
\text { prevention of skin } \\
\text { cancer, the use of } \\
\text { protective } \\
\text { accessories, such as } \\
\text { a hat and long pants, } \\
\text { was more observed } \\
\text { in females. }\end{array}$ \\
\hline 3 & $\begin{array}{l}\text { Rocha et al, } \\
2018[11]\end{array}$ & $\begin{array}{l}\text { A cross-sectional } \\
\text { descriptive study. }\end{array}$ & $\begin{array}{l}\text { Evaluate the knowledge } \\
\text { about sun exposure of } \\
\text { medical students } \\
\text { correlating with the } \\
\text { applicability of this } \\
\text { information in their } \\
\text { habits. }\end{array}$ & $\begin{array}{l}\text { Conducted with } \\
\text { students enrolled in } \\
\text { the medical course of } \\
\text { the University of } \\
\text { Passo Fundo (UPF), } \\
\text { Rio Grande do Sul. } \\
\text { Data were collected } \\
\text { from July to } \\
\text { December 2016. To } \\
\text { calculate the sample } \\
\text { size, the total number } \\
\text { of students enrolled in } \\
\text { the first semester of } \\
2016 \text { (525 students), } \\
\text { an estimated } \\
\text { prevalence of } \\
\text { photoprotection } \\
\text { practices of } 50 \% \text {, and } \\
93 \% \text { confidence level, } \\
\text { resulting in a } \\
\text { minimum initial } \\
\text { sample of } 203 \\
\text { students, was taken as } \\
\text { a starting point. The } \\
\text { sample obtained was } \\
207 \text { students, all of } \\
\text { the age, at any stage } \\
\text { of the medical course. }\end{array}$ & $\begin{array}{l}\text { The data obtained in } \\
\text { this work associated } \\
\text { with information } \\
\text { obtained in other } \\
\text { studies allow us to } \\
\text { conclude that both } \\
\text { in our reality and in } \\
\text { other locations the } \\
\text { medical students are } \\
\text { not aware of the } \\
\text { importance of } \\
\text { photoprotection, as } \\
\text { they do not apply } \\
\text { theoretical in } \\
\text { knowledge everyday practice. }\end{array}$ \\
\hline
\end{tabular}




\begin{tabular}{|c|c|c|c|c|c|}
\hline 4 & $\begin{array}{l}\text { Rebelo et al, } \\
2018[12]\end{array}$ & $\begin{array}{l}\text { A descriptive, } \\
\text { observational, } \\
\text { cross-sectional, } \\
\text { and quantitative } \\
\text { study. }\end{array}$ & $\begin{array}{l}\text { Identify the presence of } \\
\text { premature skin aging in } \\
\text { fishermen from } \\
\text { Salinópolis/PA }\end{array}$ & $\begin{array}{l}\text { Carried out with } 275 \\
\text { volunteers from the } \\
\text { Fishing Colony, from } \\
\text { three beaches in the } \\
\text { municipality of } \\
\text { Salinópolis/PA. } \\
\text { Beach fishermen, } \\
\text { aged between } 18 \text { and } \\
59 \text { years, from } \\
\text { phototype I to VI, } \\
\text { according to } \\
\text { Fitzpatrick's } \\
\text { classification (1976), } \\
\text { exposed directly to } \\
\text { solar radiation and } \\
\text { working for more } \\
\text { than one year in the } \\
\text { profession } \\
\text { included. }\end{array}$ & $\begin{array}{l}\text { A prevalence of } \\
\text { beach workers aged } \\
26 \text { to } 35 \text { years }(36 \% \text {, } \\
\mathrm{n}=98), \text { smokers } \\
(59 \%, \mathrm{n}=161), \\
\text { alcoholics }(78 \%, \mathrm{n}= \\
237) \text { and who did } \\
\text { not have skin care } \\
(91 \%, \mathrm{n}=250) \text { was } \\
\text { observed. }\end{array}$ \\
\hline 5 & $\begin{array}{l}\text { Kaddourah et } \\
\text { al, } 2015 \text { [13] }\end{array}$ & $\begin{array}{l}\text { Case study, } \\
\text { exploratory } \\
\text { research. }\end{array}$ & $\begin{array}{l}\text { To verify the } \\
\text { relationship between the } \\
\text { occurrence of irritative } \\
\text { contact dermatitis and } \\
\text { the use of Personal } \\
\text { Protective Equipment } \\
\text { (PPE), identifying risk } \\
\text { factors and measures } \\
\text { adopted }\end{array}$ & $\begin{array}{l}\text { Held in São Paulo, the } \\
\text { patients were selected } \\
\text { from the company } \\
\text { "INMETRA } \\
\text { Occupational Safety } \\
\text { Medicine and } \\
\text { Engineering. We } \\
\text { interviewed } 100 \\
\text { patients aged } 18 \text { to } 63 \\
\text { years (81 males and } \\
19 \text { females), } 30 \text { white, } \\
26 \text { black, and } 44 \\
\text { brown. Regarding the } \\
\text { level of education, } 6 \\
\text { were illiterate, } 37 \\
\text { completed only } \\
\text { elementary school, } 51 \\
\text { attended high school } \\
\text { and only } 6 \text { entered } \\
\text { higher education. The } \\
\text { interviewees worked } \\
\text { between } 12 \text { days and } \\
39 \text { years, and the } \\
\text { positions with the } \\
\text { highest incidence } \\
\text { were related to the } \\
\text { construction sector } \\
\text { (50 helpers and/or } \\
\text { construction masons, } \\
\text { assistants, math in } \\
\text { carpenters) followed } \\
\text { by food workers ( } 20 \\
\text { assistants/kitchen } \\
\text { helpers, waiters, and } \\
\text { bartenders) and the } \\
\text { others held jobs ind } \\
\text { commerce and health. }\end{array}$ & $\begin{array}{l}\text { The present study } \\
\text { verified an incidence } \\
\text { rate of dermatitis } \\
\text { due to PPE use of } \\
27 \% \text {, pointed to } \\
\text { hands as the place of } \\
\text { greatest } \\
\text { involvement, and } \\
\text { observed that the } \\
\text { major cause of } \\
\text { dermatitis is the } \\
\text { prolonged use of } \\
\text { equipment by } \\
\text { excessive working } \\
\text { hours followed by } \\
\text { exchanges with less } \\
\text { than one day. }\end{array}$ \\
\hline
\end{tabular}


International Journal of Engineering and Applied Sciences (IJEAS)

ISSN: 2394-3661, Volume-7, Issue-4, April 2020

\begin{tabular}{|c|c|c|c|c|c|}
\hline 6 & $\begin{array}{l}\text { Almeida et al, } \\
2018[14]\end{array}$ & $\begin{array}{l}\text { A } \\
\text { cross-sectional, } \\
\text { quantitative } \\
\text { study. }\end{array}$ & $\begin{array}{l}\text { Identify the } \\
\text { socio-demographic and } \\
\text { work profile of CHA } \\
\text { and verify associations } \\
\text { with the use of PPE. }\end{array}$ & $\begin{array}{l}\text { It was held in the state } \\
\text { of São Paulo, Brazil. } \\
\text { The study population } \\
\text { consisted of } 166 \\
\text { CHA. } \\
\text { The majority of CHA } \\
(94.16 \% \text { ) are women, } \\
\text { with a mean age of } \\
34.80 \text { years (standard } \\
\text { deviation - SD - } 9.96 \text {; } \\
\text { minimum } 19 \text { and } \\
\text { maximum } 62 \text { years), } \\
\text { where } 71.53 \% \text { were } \\
\text { among19 and } 39 \\
\text { years old. }\end{array}$ & $\begin{array}{l}\text { CHA is } \\
\text { predominantly } \\
\text { female and young } \\
\text { adults. The average } \\
\text { time of operation } \\
\text { was three years and } \\
\text { the mean, the most } \\
\text { used means of } \\
\text { transport for } \\
\text { activities was the } \\
\text { bicycle. } \\
\text { Most reported using } \\
\text { some type of PPE, } \\
\text { the most frequent } \\
\text { were sunscreen and } \\
\text { closed shoes. The } \\
\text { CHA with the } \\
\text { longest service time } \\
\text { is the ones that use } \\
\text { PPE the most. There } \\
\text { was a low frequency } \\
\text { of wearing a cap, } \\
\text { sunglasses, and } \\
\text { raincoat. }\end{array}$ \\
\hline 7 & $\begin{array}{l}\text { Frighetto et al, } \\
2018[15]\end{array}$ & $\begin{array}{l}\text { Exploratory } \\
\text { descriptive } \\
\text { cross-sectional } \\
\text { approach } \\
\text { quali-quantitative } \\
\text {. }\end{array}$ & $\begin{array}{l}\text { To verify the degree of } \\
\text { knowledge among } \\
\text { community health } \\
\text { agents about the harmful } \\
\text { factors caused to the } \\
\text { skin through solar } \\
\text { radiation and protective } \\
\text { mechanism against skin } \\
\text { cancer. }\end{array}$ & $\begin{array}{l}\text { Carried out in the } \\
\text { municipality of } \\
\text { Ji-Paraná/RO, } 3 \text { UBS } \\
\text { were selected the } \\
\text { sample was } \\
\text { probabilistic by } \\
\text { convenience, } \\
\text { composed of } 34 \text { CHA } \\
\text { who worked in the } \\
\text { selected UBS. A } \\
\text { questionnaire adapted } \\
\text { from Lo Turco } \\
\text { (2010) was used as a } \\
\text { data collection } \\
\text { instrument. The } \\
\text { municipalities of } \\
\text { Ananindeua and } \\
\text { Belém, Para, were } \\
\text { elected as the study } \\
\text { site. The sample was } \\
\text { due to } \\
\text { non-probabilistic } \\
\text { convenience } \\
\text { sampling, so the } \\
\text { research included } \\
\text { CHAS that on } \\
\text { pre-scheduled dates } \\
\text { would be available to } \\
\text { participate. }\end{array}$ & $\begin{array}{l}\text { It concludes that due } \\
\text { to the high sun } \\
\text { exposure and lack of } \\
\text { personal protective } \\
\text { equipment } \\
\text { adequately, skin } \\
\text { lesions correlated } \\
\text { with ultraviolet } \\
\text { radiation exposure } \\
\text { can be caused. } \\
\text { Therefore, r it } \\
\text { emphasizes that } \\
\text { more study with } \\
\text { such a population } \\
\text { and preventive } \\
\text { measures of health } \\
\text { education ran } \\
\text { necessary. }\end{array}$ \\
\hline
\end{tabular}




\begin{tabular}{|c|c|c|c|c|c|}
\hline 8 & $\begin{array}{l}\text { Araújo et al, } \\
2016[1]\end{array}$ & $\begin{array}{l}\text { Cross-sectional } \\
\text { study }\end{array}$ & $\begin{array}{l}\text { Investigate skin lesions } \\
\text { related to or aggravated } \\
\text { with sun exposure in } \\
\text { community health } \\
\text { agents in two } \\
\text { municipalities in the } \\
\text { metropolitan region of } \\
\text { Belém, State of Pará, } \\
\text { relating them to some } \\
\text { sociodemographic } \\
\text { variables, and to } \\
\text { evaluate the use of } \\
\text { protection against sun } \\
\text { exposure. }\end{array}$ & $\begin{array}{l}\text { Carried out in the } \\
\text { municipality of } \\
\text { Ji-Paraná/RO, } 3 \text { BHU } \\
\text { were selected the } \\
\text { sample was } \\
\text { probabilistic by } \\
\text { convenience, } \\
\text { composed of } 34 \text { CHA } \\
\text { who worked in the } \\
\text { selected BHU. A } \\
\text { questionnaire adapted } \\
\text { from Lo Turco } \\
\text { (2010) was used as a } \\
\text { data collection } \\
\text { instrument } \\
\text { municipality of } \\
\text { Ananindeua and } \\
\text { Belém, Pará was } \\
\text { elected as the study } \\
\text { site. The sample was } \\
\text { due to } \\
\text { non-probabilistic } \\
\text { convenience } \\
\text { sampling, so the } \\
\text { research included } \\
\text { CHAS that on } \\
\text { pre-scheduled dates } \\
\text { would be available to } \\
\text { participate. }\end{array}$ & $\begin{array}{l}\text { The results showed } \\
\text { that there is no } \\
\text { correlation between } \\
\text { skin lesions due to } \\
\text { the number of hours } \\
\text { exposed to solar } \\
\text { radiation. However, } \\
\text { when dividing them } \\
\text { into a time of } \\
\text { service, he noticed } \\
\text { that CHA working } \\
\text { in the profession } \\
\text { with more than } 3 \\
\text { years, the presence } \\
\text { of keratosis, and } \\
\text { seborrhea was } \\
\text { observed and that } \\
\text { those who worked } \\
\text { more than } 10 \text { years } \\
\text { in the profession } \\
\text { were } 3.3 \text { times more } \\
\text { likely to develop } \\
\text { melasma. }\end{array}$ \\
\hline 9 & $\begin{array}{l}\text { Pereira,2015 } \\
{[17]}\end{array}$ & $\begin{array}{l}\text { Bibliographic } \\
\text { review }\end{array}$ & $\begin{array}{l}\text { Guide the work doctor } \\
\text { on the subject and } \\
\text { improve occupational } \\
\text { skin cancer prevention } \\
\text { strategies. }\end{array}$ & 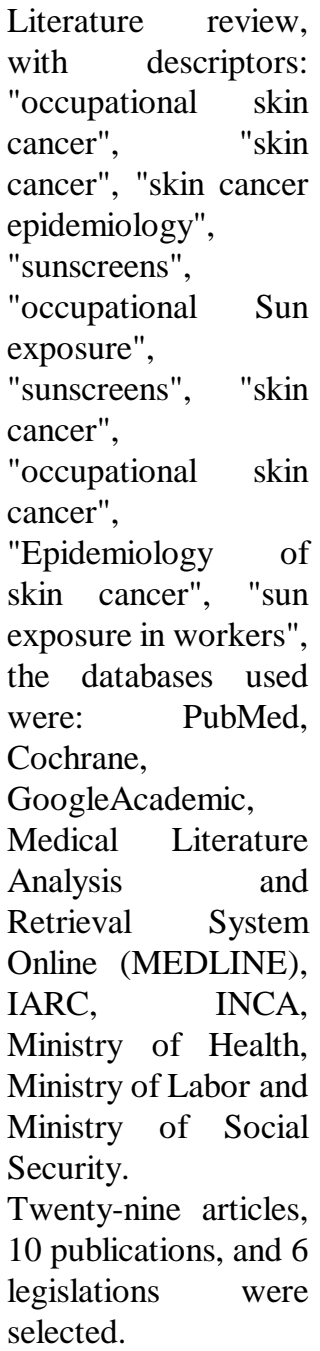 & $\begin{array}{l}\text { Research shows that } \\
\text { to reduce cases of } \\
\text { skin cancer in } \\
\text { workers exposed to } \\
\text { the sun, preventive } \\
\text { and continuous } \\
\text { follow-up of the } \\
\text { occupational } \\
\text { physician is } \\
\text { necessary }\end{array}$ \\
\hline
\end{tabular}




\begin{tabular}{|c|c|c|c|c|c|}
\hline 10 & $\begin{array}{l}\text { Souza, et al } \\
2016[18]\end{array}$ & $\begin{array}{l}\text { Cross-sectional } \\
\text { study. }\end{array}$ & $\begin{array}{l}\text { To identify risk factors, } \\
\text { sun exposure habits, } \\
\text { photoprotection and } \\
\text { skin changes in } \\
\text { Community Health and } \\
\text { Endemic Agents } \\
\text { operating in the } \\
\text { municipality of Mateus } \\
\text { Leme, Minas Gerais, } \\
\text { Brazil. }\end{array}$ & $\begin{array}{l}\text { The research in the } \\
\text { municipality of } \\
\text { Mateus Leme/MG. } \\
\text { The sample consisted } \\
\text { of } 33 \text { CHA and } 23 \\
\text { agents to combat } \\
\text { ACE endemic } \\
\text { diseases, } \\
\text { questionnaire a } \\
\text { containing } \\
\text { assessment of photo } \\
\text { exposure habits, } \\
\text { photoprotection and } \\
\text { risk factors for skin } \\
\text { cancer, associated } \\
\text { with a brief physical } \\
\text { examination of the } \\
\text { parts of the body that } \\
\text { are commonly most } \\
\text { exposed to the sun: } \\
\text { the face, neck, arms, } \\
\text { hands, trunk, and } \\
\text { back. }\end{array}$ & $\begin{array}{l}\text { The results revealed } \\
\text { that } 50 \% \text { of the } \\
\text { CHA presented at } \\
\text { least one skin } \\
\text { alteration and } 18 \% \\
\text { more than one } \\
\text { alteration. } \\
\text { Therefore, it is } \\
\text { perceived the need } \\
\text { to carry out } \\
\text { prevention and } \\
\text { skincare programs } \\
\text { after the onset of } \\
\text { lesions in the regions } \\
\text { most exposed to } \\
\text { radiation. }\end{array}$ \\
\hline 11 & $\begin{array}{l}\text { Malcher, et al } \\
2019[19]\end{array}$ & $\begin{array}{l}\text { Descriptive } \\
\text { quantitative, } \\
\text { cross-sectional } \\
\text { study. }\end{array}$ & $\begin{array}{l}\text { To evaluate the } \\
\text { photoprotection } \text { of } \\
\text { Community Health } \\
\text { Agents (CHA) of } 5 \\
\text { family health strategy } \\
\text { teams. }\end{array}$ & $\begin{array}{l}\text { Two neighborhoods } \\
\text { of the municipality of } \\
\text { Belém, Pará, were } \\
\text { elected. The study } \\
\text { population was } \\
\text { composed of } 64 \\
\text { CHA. Data were } \\
\text { collected through a } \\
\text { self-administered } \\
\text { questionnaire on sun } \\
\text { exposure habits. }\end{array}$ & $\begin{array}{l}\text { The results showed } \\
\text { that CHA is exposed } \\
\text { for a long period } \\
\text { daily to solar } \\
\text { radiation. When } \\
\text { analyzing the form } \\
\text { of photoprotection } \\
\text { of CHAs, they were } \\
\text { considered } \\
\text { inadequate when } \\
\text { using sunscreens } \\
\text { and some } \\
\text { professionals } \\
\text { reported not using } \\
\text { sunscreens. }\end{array}$ \\
\hline 12 & $\begin{array}{l}\text { Flumian, et al } \\
2018[20]\end{array}$ & $\begin{array}{l}\text { This is qualitative } \\
\text { research designed } \\
\text { as exploratory } \\
\text { action research. }\end{array}$ & $\begin{array}{l}\text { To investigate the work } \\
\text { of } 8 \text { community health } \\
\text { agents based on the } \\
\text { Focal Group Technique, } \\
\text { seeking to know and } \\
\text { analyze the sources and } \\
\text { types of overloads } \\
\text { arising from work } \\
\text { activity, working } \\
\text { conditions, employment, } \\
\text { training, and attributions } \\
\text { of this worker in the } \\
\text { Family Health Strategy. }\end{array}$ & $\begin{array}{l}\text { The study was carried } \\
\text { out in a UBS in the } \\
\text { interior of São Paulo. } \\
\text { All CHAs (10) of } \\
\text { two-family health } \\
\text { teams in which one of } \\
\text { the authors worked } \\
\text { during the two years } \\
\text { of her } \\
\text { multi-professional } \\
\text { residency in health } \\
\text { (PRMSFC-UFSCar) } \\
\text { was invited to } \\
\text { participate in the } \\
\text { study. The sample } \\
\text { consisted of } 08 \text { CHA. }\end{array}$ & $\begin{array}{l}\text { It is concluded that } \\
\text { there is no } \\
\text { recognition of the } \\
\text { importance of these } \\
\text { professionals and } \\
\text { the lack of } \\
\text { autonomy over their } \\
\text { work contributes to } \\
\text { the feeling of } \\
\text { professional } \\
\text { devaluation. }\end{array}$ \\
\hline
\end{tabular}




\begin{tabular}{|c|c|c|c|c|c|}
\hline 13 & $\begin{array}{l}\text { Garcia, et al } \\
2019[21]\end{array}$ & $\begin{array}{l}\text { A descriptive, } \\
\text { cross-sectional } \\
\text { study with a } \\
\text { quantitative } \\
\text { approach. }\end{array}$ & $\begin{array}{l}\text { Identify the profile and } \\
\text { describe the work } \\
\text { process of Community } \\
\text { Health Agents (CHA). }\end{array}$ & $\begin{array}{l}\text { The selected } \\
\text { municipalities were } \\
\text { Cariacica, Serra, Vila } \\
\text { Velha and Vitória, in } \\
\text { the state of Espírito } \\
\text { Santo, the sample } \\
\text { consisted of } 291 \\
\text { CHA. } \\
\text { For data collection, a } \\
\text { questionnaire with the } \\
\text { following variables } \\
\text { was used: time of } \\
\text { action; the number of } \\
\text { families under the } \\
\text { responsibility of the } \\
\text { CHA; one considers } \\
\text { the work stressful, } \\
\text { work bond; search for } \\
\text { another job; training } \\
\text { course and activities } \\
\text { practiced. }\end{array}$ & $\begin{array}{l}\text { The results } \\
\text { highlighted that } \\
\text { many professionals } \\
\text { report insecurity } \\
\text { regarding the work } \\
\text { bond, work } \\
\text { overload due to the } \\
\text { excessive amount of } \\
\text { activities to be } \\
\text { performed, and } \\
\text { consider work very } \\
\text { stressful. }\end{array}$ \\
\hline
\end{tabular}

Table 1: Relationship between years of published articles and results obtained.

\section{DISCUSSION}

CHA spends much of their work hours exposed, outside the basic health unit that works, with this have great exposures to the sun rays, along with other environmental factors. Sun exposure can provide health benefits and harms, in which the most noticeable are: premature aging, injuries, which can lead to skin cancer [22].

Most CHA works more than 6 hours a week in an external environment, prevailing the hours often in the morning and three in the afternoon, this daily and mandatory journey causes them to be exposed for a long time, thus increasing the risks of skin lesions [16].

In a survey conducted by Frighetto et al [15], showed that about sun exposure time $44 \%(n=15)$ is exposed from the period between 8:00 and 10:00 or after 16:00 hours, and 47\% $(n=16)$ are exposed at all times, regarding the frequency of sunscreen use, $6 \%(n=2)$ do not use sunscreen, $23 \%(n=8)$ use the times and $71 \%(n=24)$ use daily, regarding the number of times they use the protector $38 \%(\mathrm{n}=13)$ use only once a day, $26.5 \%(n=9)$ twice, respectively three or more times. For the protection of ultraviolet radiation, devices such as; sunscreen, long clothing, hat or cap, sunglasses, and umbrellas, but only $9 \%(n=3)$ of the CHA use all these means, $14.71 \%(n=5)$ use only one means of protection, the others vary between two and four methods used to protect themselves. Regarding knowledge about skin cancer, $79 \%(n=27)$ have heard about it.

Sunscreens are indispensable prevention methods, but not all CHA have access due to several factors such as self-cost, not necessarily provided by municipal administrations, or make the misuse of it, which may have occurred due to lack of information on the importance and correct form for use. Another method that we can highlight as a form of prevention is mechanical protectors, such as hats, sun umbrellas, which, like sunscreen, are not part of the daily lives of many [23].

According to Souza [18], most of the servants know the importance of using sunscreen, and what can happen with the non-use of them. However, disuse or incorrect application stands out with prevalence, requiring a protection alert with more information that enhances your care correctly.

In a study based on the evaluation of the skin of CHA, it was reported that half of them already had 1 type of skin lesion, and were affected either by immediate or late changes due to exposure, almost $20 \%$ of those evaluated found more than one alteration. And in this population, $5 \%$ have already been detected with skin cancer [24].

Brazil, due to its tropical climate, is with a high percentage of solar rays and together with this factor, one can also mention the little information focused on this theme and the Brazilian cultural issue of not making the use of sunscreens daily. Because of this, skin cancer has a percentage of $25 \%$ of other tumors present in all regions [25].

In New Zealand, it was proven through a study done with 1,061 workers of high sun exposure that, they make proper use of PPE and possess full support of employers by providing them and appropriate guidance for their protection realizing that the most used were hats, sunglasses and sunscreens [26].

When the skin passes through solar aggressions it tends to

give apparent signs from spots, dryness, roughness, to lesions that can be classified according to the degree it is and maybe benign, premalignant, reaching even malignant [27] [28].

Skin aging can act as a warning sign, in which process is occurring in an accelerated manner and acting in similar to other factors, such as inadequate eating, stress, sedentary lifestyle, smoking, excess alcohol, pollution, or genetic predisposition [29].

According to Haack [30] research conducted in the city of Pelotas showed that $44.4 \%$ of the participants presented sensitivity when exposed to the sun, generating mild burns. 
The other half of the individuals surveyed reported that they do not use sunscreens in the workplace and leisure.

According to the Brazilian Society of Dermatology [31], it is essential that CHA participate in campaigns or programs that bring information rich in health education more frequently, and that they show, from the main ways of performing self-care, showing the importance that this acts against daily solar radiation, to the consequences that this exposure without protection and inadequate maintenance of it can cause immediate or in the long term. So that they acquire a more acute self-care and are more aware and able to pass this on to the population that also needs this primary prevention.

The health promotion carried by the trained and well-oriented CHA has a fundamental and unparalleled role in the population, where in addition to providing knowledge, it becomes able to create a link of trust [32].

\section{CONCLUSION}

It was found that most studies were conducted in the southeast region. It was observed that the vast majority of professionals who work in contact with sun exposure, do not use or improperly apply and maintain photoprotection, and do not use mechanical protective scans (clothes, hats, glasses, and sun umbrellas) together. Moreover, most of these workers present some type of skin lesion, generated by exposure to solar radiation for excessive and inadequate time.

In the face of this, this review raised two fronts of work and research. The first refers to the need to appropriate the results of research by managers and policymakers and, the second, to the need for investment in studies and constant training for difficulties faced by the CHA in its work, such as valuing the importance of self-care with health and the dissemination of these guidelines correctly for the entire population, helping to decrease the high percentage of skin lesions caused by solar radiation from the communities.

In this sense, new studies are important in Brazilian regions with different realities.

\section{REFERENCES}

[1] Brasil. Ministério da Saúde. PNAB: Política nacional de atenção básica. Brasília: Ministério da Saúde, 2012.

[2] Martines, W.R.V. Compreendendo o processo de sofrimento no trabalho do Agente Comunitário de Saúde no Programa Saúde da Família. São Paulo: USP, 2005. Dissertação [Mestrado em Ciências da Saúde] -Escola de Enfermagem da USP, 2005.

[3] Flor, J.; Davalos, M.R.; Correa, M.A. Protetores solares. Revista Química Nova, São Paulo, v. 30, n. 1, p. 153-158, 2007.

[4] Montagner, S.; Costa, A. Bases biomoleculares do fotoenvelhecimento. Anais Brasileiros de Dermatologia, Rio de Janeiro, v. 84, n. 3, p. 263-269, 2009.

[5] Gontijo, G.T.; Pugliesi, M.C.C.; Araújo, F.M. Fotoproteção. Surgical \& Cosmetic Dermatology, Rio de Janeiro, v. 1, n. 4, p. 186-192, 2009.

[6] Azulay, R.D. Dermatologia. 7. ed. Rio de Janeiro: Guanabara Koogan, 2017.
[7] Meyer, P.F.; et al. Investigação sobre a exposição solar em trabalhadores de praia. Revista Brasileira em Promoção da Saúde, Fortaleza, v. 25, n. 1, p. 103-109, 2012.

[8] Carvalho, G.F. et al. Avaliação dos efeitos da radiofrequência no tecido Conjuntivo. Revista brasileira de medicina, Rio de Janeiro, v. 68, p. 10-25, 2011.

[9] Cortez, D.A.G. et al. O conhecimento e a utilização de filtro solar por profissionais da beleza. Ciência \& Saúde Coletiva, v. 21, p. 2267-2274, 2016.

[10] Castro, D.S.P.; Lange, C.; Pastore, C. A.; Carreira, L. et al. Câncer de pele em idosos rurais: prevalência e hábitos de prevenção da doença. Saúde e Pesquisa, v. 11, n. 3, p. 495-503, 2018.

[11] Rocha, C. R. M.D.; Tronco, A.; Borba, F.W.; Lunelli, J. et al. Fotoexposição: Hábitos e Conhecimento de Estudantes de Medicina. Rev. bras. ciênc. saúde, p. 149-154, 2018.

[12] Rebelo, E.B.; Lobato, T. M. X.; da Silva, W. G.; Bandeira, C. C. A. et al. Exposição solar e envelhecimento precoce em trabalhadores praianos do município de Salinópolis/PA. Estudos Interdisciplinares sobre o Envelhecimento, v. 23, n. 3, 2018.

[13] Kaddourah, S. M. E. H.; Costa, F.; Fábrega, J. F.; Rabello, L. et al. Relação entre a ocorrência de dermatite de contato irritativa e o uso dos equipamentos de proteção individual. Revista Brasileira de Medicina do Trabalho, p. 120-125, 2015.

[14] Almeida, M.C.S.; Barros, V. G.; Baptista, P.C.P.; Silva, A. et al. Fatores relacionados ao uso de EPI em agentes comunitários de saúde. Rev Bras Med Trab. 2018;16(3):346-52

[15] Frighetto, A.V. et al. Câncer De Pele: Avaliação, conhecimento e Identificação em Agentes Comunitários De Saúde Do Município De Ji-Paraná-Ro. BrazilianJournal of Surgery and Clinical Research, Paraná, v. $25, \mathrm{n} 2$, p.38-42, 2018

[16] Araújo, F.C. et al. Avaliação dermatológica de agentes comunitários de saúde sujeitos à fotoexposição em região tropical do Brasil. Scientia Medica, v. 26 , n. 4 , p. 1,2016

[17] Pereira, C.A. A importância da atuação do médico do trabalho na prevenção do câncer de pele ocupacional. Rev. bras. med. trab, p. 73-79, 2017.

[18] Souza, M.C.M.R. et al. Câncer de pele: hábitos de exposição solar e alterações cutâneas entre agentes de saúde em um município de Minas Gerais. Revista de Enfermagem do Centro-Oeste Mineiro, 2016.

[19] Malcher, C.M.S.R.; Tembra, A.L.; Amorim, F.C.; de Souza, T. R. M. et al. Fotoproteção em Agentes Comunitários de Saúde (ACS) de Belém-PA. Revista Brasileira de Medicina de Família e Comunidade, v. 14, n. 41, p. 1-9, 2019.

[20] Flumian, R. B.; Fioroni, L.N.; Fioroni, L.N. Aproximações às vicissitudes e superações do trabalho do Agente Comunitário de Saúde Tempus Actas de Saúde Coletiva, v. 11, n. 2, p. 179-198, 2018.

[21] Garcia, A.C.P.; Lima, R.C.D., Lima, E.F.A.; Galavote, H.S.et al. Perfil e o Processo de Trabalho dos Agentes Comunitários de Saúde. Revista de Pesquisa: Cuidado é Fundamental, p. 339-344, 2019.

[22] Kumar V.; Abbas A.K.; Aster J. C. Robbins \& Cotran - Bases Patológicas das Doenças. 9a ed. Rio de Janeiro: Elsevier; 2016.

[23] Schalka, S.; et al. Brazilian consensus on photoprotection. Anais Brasileiros Dermatologia, Rio de Janeiro, v. 89, n. 6, p. 1-74, 2014. http://dx.doi.org/10.1590/abd1806-4841.20143971.

[24] Milesi, Sabrine da S.; Guterres, Silvia Stanisçuaski. Fatores determinantes da eficácia de fotoprotetores. Caderno de farmácia. Porto Alegre, RS. Vol. 18, n. 2, p. 81-87, 2002. 
[25] Souza, S. R. P., Fisher, Frida M.; Souza, J. M. P. Bronzeamento e risco de melanoma cutâneo: revisão da literatura. Revista de Saúde Pública v.38, n.4, São Paulo, agosto 2004.

[26] Reeder, A.I.; Gray, A.; Mccool, J.P. Occupational sun protection: workplace culture, equipment provision and outdoor workers' characteristics. Journal of occupational health, v. 55, n. 2, p. 84-97, 2013.

[27] Silva, S.A.M; Michniak-Kohn, B; Leonardi, G.R. An overview about oxidation in clinical practice of skin aging. Anais Brasileiros de Dermatologia, São Paulo, v. 92, n. 3, p. 367-374, jun. 2017.

[28] Batistela, M.A.; Chorilli, M.; Leonardi, G.R. Abordagens no estudo do envelhecimento cutâneo em diferentes etnias. Rev. Bras. Farm, v. 88, n. 2, p. 59-62, 2007

[29] Pandolfo, M. O processo de envelhecimento. Personalite, [s.1.], v. 14, n. 71 , p. $102-114,2011$
[30] Haack, R. L.; Horta, B. L.; Cesar, J. A. Sunburn in young people: population-based study in Southern Brazil. Revista de saúde pública, v. 42, n 1, p. 26-33, 2008.

[31] Sociedade Brasileira de Dermatologia. Consenso Brasileiro de Fotoproteção. 2013. Rio de Janeiro: SBD, 2013.

[32] Nunes, M.O. et al. O agente comunitário de saúde: construção da identidade desse personagem híbrido e polifônico. Cadernos de Saúde Pública, v. 18, n. 6, p. 1639-1646, 2002. 